ReVISTA ARA No5 5 Volume 5 . PrIMAVERA+VERÃo 2018 • GRUPO MUSEU/PATRIMÔNIO FAU-USP

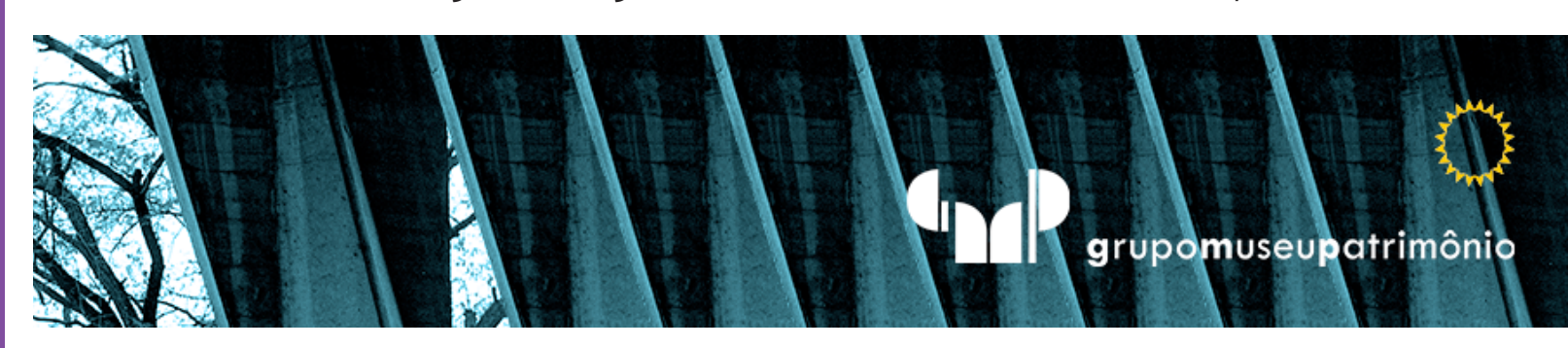

\title{
Palimpsesto Auri-verde
}

Palimpsesto Auri-verde

Auri-green Palimpsest

Amanda Saba Ruggiero

Pós-Doutoranda da Faculdade de Arquitetura e Urbanismo, Universidade de São Paulo, Membro do Grupo Museu/Patrimônio, São Paulo, Brasil. amandaruggiero@gmail.com

Marcia Sandoval Gregori

Doutoranda da Faculdade de Arquitetura e Urbanismo da Universidade Presbiteriana Mackenzie, Membro do Grupo Museu/Patrimônio, São Paulo, Brasil. marciagregori@hotmail.com 


\section{Resumo}

O artigo analisa os vários níveis de significado que a bandeira e suas cores predominantes, o verde e o amarelo, imprimem de tempos em tempos sobre episódios políticos, manifestações culturais e movimentos sociais, a configurar indeterminações e limites imprecisos. As cores evocam união nacional, mas em alguns casos podem dissimular profundas rupturas sociais. A temática nacionalista desperta interesse, em pleno período de copa do mundo aliada à desenfreada instalação de estandartes nacionais nas principais avenidas e pontes da cidade de São Paulo, quando a grave crise política e econômica acentua as disputas sociais no país.

Palavras Chave: Bandeira, Nacionalismo, verde-amarelo, história, São Paulo.

\section{Abstract}

The article analyzes the various levels of meaning that the brazilian nationa flag and its predominant colors, green and yellow, print from time to time on political episodes, cultural manifestations and social movements configuring indetermination and inaccurate limits. The colors evoke national union but in some cases could conceal profound social ruptures. The nationalist theme arouses interest, in World Cup period together with unrestrained installation of national banners on the main avenues and bridges of the city of São Paulo, when the serious political and economical crisis emphasize the social dispulo, in the country.

Keywords: Flag, Nationalism, green-yellow, History, São Paulo.

\section{Resumen}

El artículo analiza los diversos niveles de significado que la bandera nacional de Brasil y sus colores predominantes, verde y amarillo, imprimen de vez en cuando sobre episodios políticos, manifestaciones culturales y movimientos sociales, configurando indeterminaciones y límites imprecisos. Los colores evocan unión nacional, pero en algunos casos pueden disimular profundas rupturas sociales. La temática nacionalista despierta interés, en pleno período de copa del mundo aliada a la desenfrenada instalación de estandartes nacionales en las principales aliada a la desenfrenada instalación de estandartes nacionales en las principales
avenidas y puentes de la ciudad de São Paulo, cuando la grave crisis política y económica acentúa las disputas sociales en el país.

Palabras-Clave: Bandera, Nacionalismo, Verde-Amarillo, Historia, São Paulo. 
embora façam uso dessa aparente identidade unívoca (como no caso do futebol) para revestir sua narrativa de suposta universalidade.

Este artigo procura investigar as várias camadas de significado que a bandeira o verde e o amarelo adquirem e imprimem sobre a configuração de fatos, objetos e movimentos na história do país. As cores que evocam união nacional, muitas vezes camuflam cisões sociais profundas. $O$ interesse em abordar o tema foi disparado pela proliferação desenfreada de bandeiras do Brasil em grandes avenidas e pontes da cidade de São Paulo em período de crise político-econômica e de acirramento das disputas sociais no país.

2018 é ano de eleições presidenciais no Brasil e, além de ser data da Copa do Mundo, relacionada ao supostamente coeso imaginário futebolístico nacional, coincide com o quinquênio das Jornadas de Junho, série de protestos iniciados em 2013 em São Paulo contra o aumento de 20 centavos das tarifas de transporte que acabou servindo de gatilho, após violenta repressão policial apoiada pela "mídia tradicional" (Rodrigues, 2018), para mobilizações de rua com centenas de milhares de pessoas em todo o país e diversidade de demandas. Aos movimentos, seguiram-se o impeachment da presidente eleita, Dilma Rousseff, em 2015, e as investigações da Operação Lava Jato, iniciada em março de 2014, que prendeu dezenas de políticos e empresários.

Neste panorama, é intrigante pensar a intenção e as possíveis consequência do movimento que instalou as bandeiras do Brasil em São Paulo e relembrar, como esforço de entendimento crítico da essência desse símbolo, as várias camadas de significação que já adquiriram o verde e o amarelo do estandarte brasileiro ao longo de sua história.

Aparentemente inofensivas, as bandeiras declaram seu amor à "pátria amada, salve, salve (...)". Bandeiras e mais bandeiras em sequências, distribuídas ao longo de pontes e avenidas, parecem celebrar o clima de copa do mundo. Afinal, "o Brasil é o país do futebol!" e os momentos de torcida e união pelo esporte são uma espécie de identidade nacional consolidada interna e externamente, reforçada pelas conquistas do mundial em 1958, 1962, 1970, 1994 e 2002.
Mas outros sentidos podem ser associados à bandeira e às cores do Brasil, sobretudo em momento atual no qual disputam-se símbolos, narrativas e imaginários. Ao longo do tempo, movimentos políticos, sociais, culturais e o Estado recorreram ao verde amarelo do estandarte. Desde a primeira bandeira, que apresentava o brasão de armas do império, passando pelo movimento literário Verde-Amarelo, pelos estudantes "caras-pintadas" em 1992, organizados em prol do impeachment do ex-presidente Fernando Collor de Mello, até aqueles que saíram recentemente pelas ruas do país, apoiando o impeachment da ex-presidente Rousseff.

Admitindo-se que o imaginário corresponde "à prática social de atribuir significados a significados, ou seja, prática social pela qual os significados passam a acumular imagens e a significar mais" (Ferrara, 1996, p.45), a bandeira do Brasil e as cores verde e amarelo, espécie de síntese do estandarte, podem ser considerados palimpsestos ${ }^{1}$, ou seja, objetos sobre os quais se depositam novas camadas de significação. Nesse processo de reescritura, sedimentos anteriores podem ser apagados, vínculos originais desfeitos e novos conteúdos depositados.

\section{A BANDEIRA E O VERDE E AMARELO}

\section{Primeiras significações da bandeira}

A primeira bandeira oficial do Brasil imperial foi criada em 1822 por JeanBaptiste Debret. Continha um retângulo verde e um losango amarelo sobre o qual destacava-se o Brasão de Armas do Império, criado a pedido de D. Pedro I (figuras 1 e 2). Segundo Milton Luz,

escolha de nossas cores nacionais não foi um mero capricho do Príncipe Regente. É que o significado das cores elegidas para representar um grupo, um povo ou uma nação, tem sempre profundas raizes históricas que tradiç̃o mantém vivas. (2005, p. 21-2)

Palimpsesto, originalmente, é um pergaminho cujo texto foi apagado a fim de receber nova escritura. 
Desse histórico, originalmente o verde, "desde aqueles tempos ancestrais, lembra as lutas libertárias, as grandes conquistas e, acima de tudo, a esperança e a liberdade". No Brasil a cor adquiriu novas acepções, "seria, muito tempo depois e nestes sertões do Novo Mundo, o pendão do nosso bandeirante Fernão Dias Paes Leme, o Governador das Esmeraldas". Ainda de acordo com Luz, a escolha do amarelo deveu-se às conquistas das fortalezas, a tomadas dos mouros, e ao Reino de Castela, ao qual Portugal pertenceu (p. 21 -2).
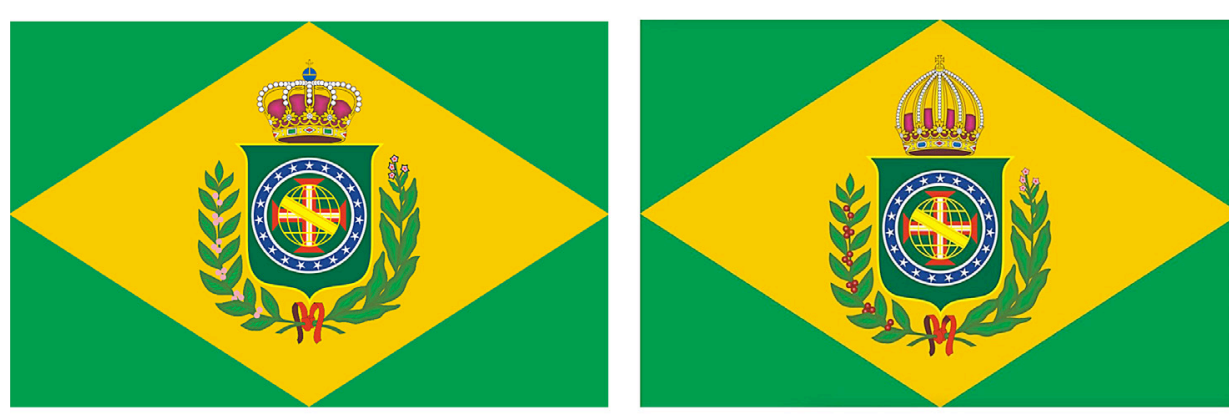

Figuras 1 e 2: À esquerda, a primeira bandeira Nacional, criada por Jean-Baptiste Debret no dia 18 de setembro de 1822 a pedido de Dom Pedro I, apresenta o losango amarelo sobre o retângulo verde e, ao centro, o Brasão de Armas do Império. Em dezembro do mesmo ano foi substituída pela Bandeira Imperial, que mantinha os mesmos elementos com algumas poucas alterações (à direita).

0 verde e o amarelo definidos na primeira bandeira de Debret se mantiveram ao longo de toda a história do estandarte brasileiro, enquanto o desenho central do brasão de armas sofreu pequenas alterações ainda durante o período do Império. Armas que remetiam ao exército recém criado pelo imperador ao declarar a independência do Brasil de Portugal, assim reforçando a ideia de uma identidade nacional assentada na simbologia da força militar, dedicada a defender fronteiras e garantir a ordem interna segundo interesses do poder instituído.

Em 1889, proclamação da República, Ruy Barbosa criou uma bandeira provisória que remetia ao estandarte dos Estados Unidos da América a partir das cores da bandeira do império. Essa versão foi utilizada apenas por 4 dias (figura 3). Logo depois, foi substituída pela versão atual, na qual manteve-se a geometria original do retângulo verde e do losango amarelo, cujo tamanho foi ligeiramente reduzido e, no centro, substituiu-se o brasão pelo círculo azu celeste sobre o qual repousavam as estrelas que representam os estados $e$ uma faixa branca com os dizeres "ordem e progresso" (figura 4).

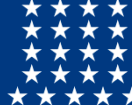

贯

Figura 3: Bandeira provisória da República criada por Ruy Barbosa.

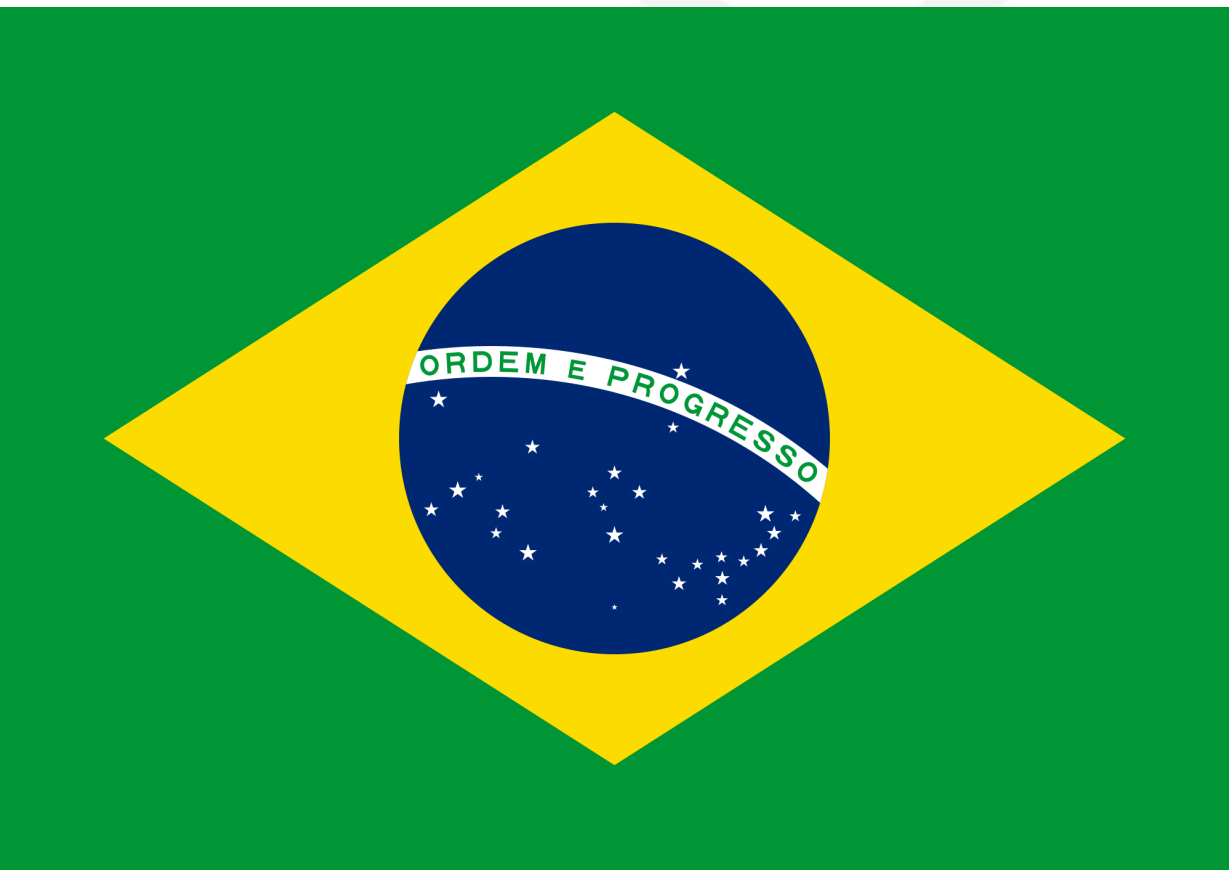

Figura 4: Bandeira do Brasil adotada a partir de 19 de novembro de 1889, logo após a proclamação da República. Criada por por Raimundo Teixeira Mendes, com a colaboração de Miguel Lemos, Manuel Pereira Reis e Décio Villares, mantinha a organização da bandeira original, substituindo o Brasão de Armas do Império pelo circulo azul sobre quá dispóem-se a faixa com os dizeres Ordeme Progresso representam as unidades federativas. 
Inspirado no lema positivista de Auguste Comte "o amor por princípio, e a ordem por base; o progresso por fim", o mote brasileiro impresso na bandeira suprimia o amor e exaltava o progresso, sugerindo a ordem como elemento necessário para alcançá-lo. Os elementos figurativos presentes na bandeira anterior foram então substituídos por princípios abstratos nos quais predominam, como afirma Gilberto Freyre (1959), o gosto pela matemática que via na engenharia e na técnica o futuro do país. Evocam-se, dessa maneira, a presença militar, determinante na formação da República, e os princípios positivistas. Seria esse o progresso almejado?

\section{O Verdeamarelismo e o nacionalismo fascista}

Já no século $X X$, em contraposição ao movimento antropofágico, surge, na literatura, o manifesto Nhengaçu Verde-Amarelo, de 1929, liderado por Cassiano Ricardo, Menotti Del Picchia e Plínio Salgado. O movimento, cujo nome se apropriou das cores originais da bandeira, exaltava o nacionalismo e o amor à pátria, recusava todo elemento estrangeiro, defendendo, de acordo com o manifesto, "todas as instituições conservadoras, pois é dentro delas mesmo que faremos a inevitável renovação do Brasil. [...] Nosso nacionalismo é 'verdamarelo' e tupi" (Schwartz, 2008, p. 185). Segundo o autor,

começam assim a se delinear os contornos de uma ideologia nacional-conservadora que, posteriormente, sob a liderança in Plinio salga

(Schwartz, 2008, p. 557)

O movimento alegava não ter preconceito, embora fosse avesso ao estrangeiro, e buscava na origem tupi, idealizada como passiva, sentimental e não beligerante, a pureza da raça brasileira, em evidente diálogo com os fascistas europeus. Os verdamarelistas eram contrários à discussão e ao pensamento intelectual, postulavam a prática e a ação produtiva como conduta criativa, alinhando-se ao lema do progresso positivista em crítica velada à postura reflexiva de Mário de Andrade:
Nosso nacionalismo é de afirmação, de colaboração coletiva, de igualdade dos povos e das raças, de liberdade do pensamento, de crença na predestinação do Brasil, na humanidade, de
(Picchia, p. 185)

A contradição prevaleceu no movimento. Por um lado defendeu-se a liberdade individual e a ausência de preconceitos e por outro procurou-se uma pureza primitiva idealizada e não mais existente ${ }^{2}$, visto que fragmentada diante de um mundo globalizado e transnacionalizado. $O$ apelo ao sentimentalismo foi também uma característica determinante do movimento que irá reaparecer em outras ocasiões da história do Brasil, como se tratará adiante.

\section{Eu te amo, meu Brasil}

No início dos anos 1960 dois irmãos cearenses radicados em São Paulo ingressaram na carreira artística como a dupla Dom \& Ravel. Em 1969 o duo lançou o primeiro LP, que contava com a música "Você também é responsável", transformada, em 1971, em hino do Mobral (Movimento Brasileiro de Alfabetização) pelo então ministro da educação, Jarbas Passarinho. Mas foi em 1970, com a canção "Eu te amo, meu Brasil", gravada pelo conjunto Os Incríveis, que os dois artistas alcançariam seu maior sucesso.

"Eu te amo, meu Brasil / Eu te amo / Meu coração é verde, amarelo, branco, azul anil" era a letra de forte apelo emocional que, segundo Ravel, fora composta "para aproveitar a onda do tricampeonato da seleção de futebol" (ALBIN, 2018). Em plena ditadura, entretanto, era difícil não associar os versos ao slogan do regime, "Brasil, Ame-o ou Deixe-o", que apelava para o ufanismo nacionalista a fim de ratificar discurso de sua conveniência, enquanto atribuía ao discurso contraditório posição de inimigo dos interesses do país.

Em A identidade cultural na pós-modernidade, Stuart Hall (2015) propõe pensar as culturas nacionais não como unificadas, mas sim como dispositivo discursivo, "que representa a diferença como unidade ou identidade"(p.36). 
Como afirma Renato Ortiz, Estados autoritários tendem a "estimular a cultura como meio de integração, mas sob o controle do aparelho estatal" em ações que procuram "integrar as partes a partir de um centro de decisão". Música, cinema, jornal, novela e futebol, entre outros, são elementos culturais de importante penetração e, em sociedades de massa, úteis na conquista dessa coesão desejada de identidade nacional, sintetizada nas cores verde e amarela, bens simbólicos consumidos em massa por uma sociedade cada ve mais habitante de centros urbanos (1985, p. 82-3).

A letra da música de Dom \& Ravel adequava-se aos objetivos da propaganda do governo ditatorial nos moldes descritos por Ortiz, mesmo quando considerada sua alegada origem futebolística. A afinidade era tanta que os dois "começaram a ser apontados como arautos da ditadura", sobretudo após a divulgação na imprensa da sugestão de transformar o sucesso musical em hino nacional, supostamente feita ao Presidente Emílio Garrastazu Médici pelo governador de São Paulo, Roberto de Abreu Sodré (Albin, 2018).

A roupagem jovial, com ritmo popular e a dramaticidade obtida pelo uso das cores da bandeira, era estratégica. Difundia uma boa imagem do governo militar, no sentido de amenizar a sisudez, popularizar sua aura e ratificar a tortura e crimes de Estado em período de grande endurecimento do regime, poucos anos após o decreto do Ato Institucional número 5 (Al-5), ocorrido em dezembro de 1968, e realçava a potência nacional por meio do esporte. Marilena Chauí descreveu a estratégia definida pelo governo militar: da nação contra sua fragmentação e dispersão em interesses regionais), a segurança nacional (contra inimigo interno e externo, isto é, a ação repressiva do Estado na luta de classes) e o desenvolvimento naciona (nos moldes das naçōes democraticas ocidentais cristâs, escolas com a disciplina de educacão moral foi feita nas televisão com programas como "Amaral Neto, o repórter"e os da Televisão Educativa, e pelo rádio por meio da "Hora do Brasil"e do Mobrall Movimento Brasileiros de Alfabetização), encarregado, de um lado, de assegurar mão de obra qualificada para o novo mercado de trabalho e outro, de destruir
Como não raras vezes, as cores da bandeira serviam como instrumento de veiculação e propagação de ideais de nacionalismo e intolerância que procuravam o silêncio das múltiplas vozes dissonantes.

\section{O movimento dos Caras-Pintadas}

Em 1992, o movimento estudantil, liderado pela União Nacional dos Estudantes (UNE) e União Brasileira dos Estudantes Secundaristas (UBES), foi às ruas pedindo o impeachment do então presidente Fernando Collor de Mello. O descontentamento com a atuação do governo federal em suas medidas econômicas impopulares, aliado aos escândalos de corrupção contra o presidente, impulsionou os jovens a sair pelas ruas manifestando-se contra o governo, vestidos de preto e pintando seus rostos de verde e amarelo, ficando assim o movimento popularmente conhecido como Caras-Pintadas. Neste momento as cores do Brasil utilizadas com o sentido de patriotismo e nacionalismo, contra a corrupção, ausentou-se dos princípios conservadores anteriores.

A participação dos estudantes, por meio da UNE, liderada pelo seu presidente Lindbergh Farias e da UBES, fortaleceu-se no final dos anos 1980 e início dos 1990, com as campanhas do passe-livre estudantil nos transportes e da meia entrada nos cinemas. Em 1989 acontecia a primeira eleição direta para presidente no Brasil desde 1964:

No confronto final entre Fernando Collor de Mello, governador de Alagoas, "representante dos setores mais conservadores da sociedade", e Luiz Inácio "Lula" da Silva, ex-sindicalista pernambucano radicado em São Bernardo 2015, p.905)

Collor, eleito sob a promessa de combater os "marajás", defender os pobres e moralizar a administração pública, construiu-se a partir da imagem do "jovem, esportivo e modernizador" e em pouco tempo no poder revelou-se afeito às antigas e conhecidas ilícitas práticas políticas como a troca de favores, 
cobrança de propinas e lavagem de dinheiro. O desastroso Plano Collor, dirigido pela professora Zélia Cardoso, congelou salários, confiscou poupanças, privatizou empresas estatais, demitiu funcionários públicos, criou novos impostos e elevou outros, em pouco tempo fracassou (Mota; Lopez, 2015, p. 906). Após as denúncias deflagradas pelo irmão do presidente, Pedro Collor de Mello, a pressão popular do movimento estudantil em todo país, engrossada por outros setores da sociedade, pressionou o Congresso para cassação do governante. Fernando Collor de Mello renunciou ao mandato antes da cassação, perdendo direitos políticos por apenas 8 anos. Em $1^{\circ}$ de janeiro de 2007 , voltou à cena política como senador da república no congresso nacional.

Naquele momento, o verde amarelo estampado na face da juventude, por um lado, expressava esperança e manifestava o poder das forças populares, por outro, anunciava a cisão interna do congresso e a perda de aliados do presidente perante Comissão Parlamentar de Inquérito (CPI) instalada, resultando em pena muito branda, permitindo rapidamente o retorno de todo arcabouço corrupto, enquanto a esperança de mudança por pouco tempo ventilou-se nas jovens mentes nacionais.

\section{Disputa simbólica de cores no processo de impeachment}

Após as chamadas Jornadas de Junho, em 2013 e a Copa do Mundo de 2014 no Brasil, em que torcedores vaiaram e xingaram a presidente Dilma Rousseff, iniciou-se na Câmara dos Deputados, a 2 de dezembro de 2015, processo de impedimento da presidente, reeleita um ano antes com $51,64 \%$ dos votos válidos, em segundo turno do pleito eleitoral.

O cenário era transversalmente crivado pela atuação do poder judiciário, estrategicamente evidenciado e celebrado pela imprensa na luta contra a corrupção, com discurso que amalgamou largos setores do país em torno de uma agenda focada no combate a políticos e empresários corruptos e que resultou em discurso contra a política em geral e em defesa de gestores.
Seguiram-se eleiç̃os municipais em 2016 nas quais houve, não por acaso, significativo número de votos brancos e nulos.

Ao longo de 2013 e dos anos seguintes, os protestos se transformaram e passaram a ter um espectro mais variado. Às pautas que inicialmente reivindicavam a redução da tarifa, o direito democrático à cidade e ampliavase na demanda pela melhoria dos demais serviços públicos, como saúde e educação, somaram-se propostas de redução de direitos trabalhistas, discussões sobre o impedimento ou a permanência da presidente da República, Dilma Rousseff, o combate à corrupção e, inclusive, o pedido pela volta dos militares ao poder, desejada por uma minoria que se viu habilitada a sair às ruas hasteando tal reivindicação.

Dividiram-se os atos, dividiu-se o país. Grupos de verde e amarelo, embora a coesão estivesse no ódio ao Partido dos Trabalhadores (PT) e fosse muito mais cromática do que resultante da convergência de outros objetivos comuns, antagonizavam os grupos vestidos de outras cores, sobretudo de vermelho, e alguns pediam a volta da ditadura militar para botar ordem no país, associando a corrupção à desordem e ao famigerado "fracasso" a que o Brasil parece estar eternamente fadado.

A cisão se intensificou ainda mais a partir de 2014, "em embate que não deveria interessar a quem não se beneficia com lugares de poder" (Rodrigues, 2018). E, em 2016, o grupo que emprestava o verde e amarelo da bandeira para suas manifestações saiu aparentemente ${ }^{3}$ vitorioso com o impeachment de Rousseff porque, no jogo de forças e influências

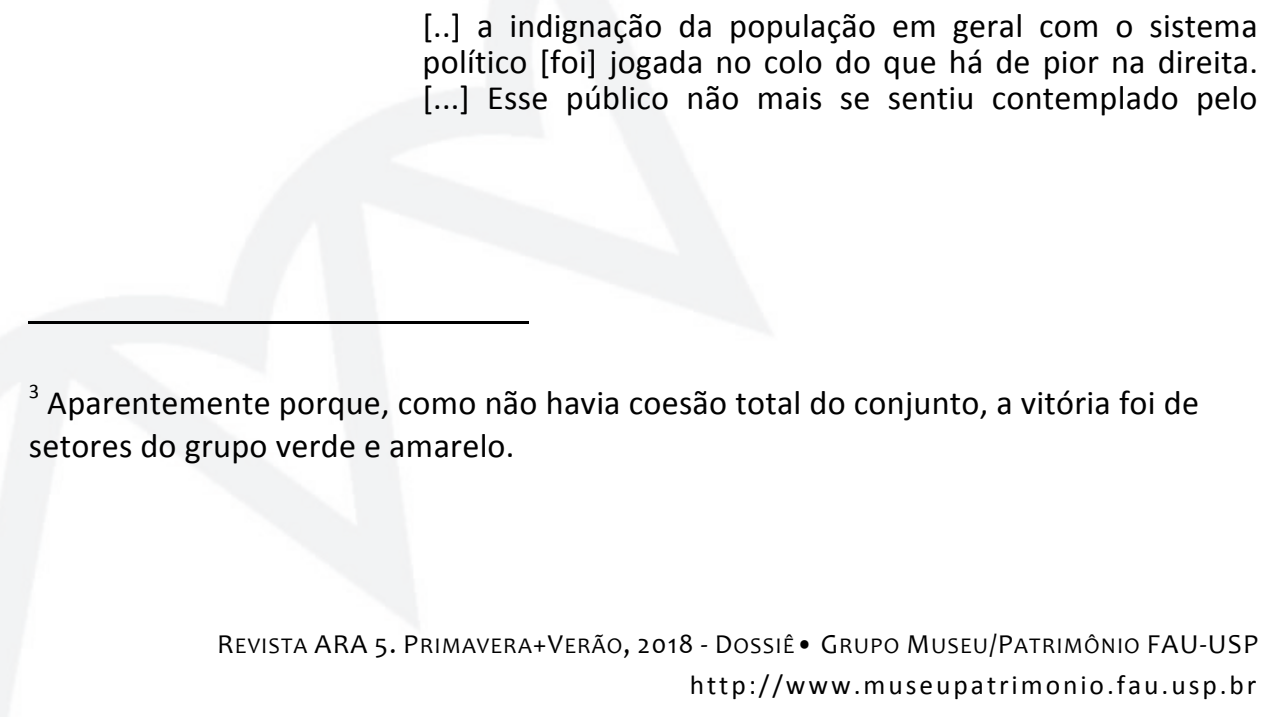


governo do mesmo partido do presidente ${ }^{4}$ com $80 \%$ de aprovação, alguns anos antes. (Rodrigues, 2018)

No congresso, a mobilização de parte das ruas significou, mais do que uma resposta ao clamor popular - visto que não havia consenso nem consulta pública quanto aos rumos a serem tomados pelo país -, a possibilidade de desestabilização do poder presidencial empossado em segundo mandato em 2015 e a consolidação de um novo equilíbrio de forças na cúpula do poder, ora baseado na imagem nacional expressa pelas cores da bandeira e na narrativa da luta contra a corrupção, incensada e diariamente repetida pela grande imprensa.

No dia 17 de abril de 2016, a Câmara dos Deputados votou a favor do impeachment. Foram 367 votos a favor, 137 votos contra, duas ausências e 7 abstenções, em pleito no qual muitos deputados dedicavam suas escolhas a suas famílias, a Deus e até a torturador ${ }^{5}$ dos chamados Anos de Chumbo pós 1964. Muitos faziam uso das cores da bandeira em peças de roupas e acessórios para destacar sua posição na contenda. Dizeres como Tchau, querida!" e "Impeachment já!", escritos em cartazes nas cores verde e amarelo, eram empunhados pelos congressistas favoráveis ao impedimento da autoridade maior do país.

Dando sequência à ação, em 31 de agosto de 2016, o Senado Federal votou pelo afastamento da presidente sem a cassação de seus direitos políticos por 61 votos a favor e 20 contra e o vice-presidente assumiu a presidência no lugar de Dilma Rousseff, que em último pronunciamento vestia vermelho, acompanhada por uma massa com roupas, bandeiras, flores e acessórios rubros.

${ }^{4}$ Referência a Luiz Inácio Lula da Silva, presidente do Brasil até 2008, que deixou o segundo mandato com $80 \%$ de aprovação.

${ }^{5}$ Um dos deputados federais favoráveis ao impeachment dedicou seu voto ao Corone Carlos Alberto Brilhante Ustra, ex-chefe do DOI-CODI do II Exercito que praticou tortura durante a ditadura pós 1964 e foi um dos responsáveis por torturar Dilm Rousseff, presa em 1970 por participar de organizaçoes politicas proibidas pelo regime. 0 voto era uma clara agressão à presidente e uma afronta aos princípios democráticos do país.
Evidenciava-se violentamente a disputa simbólica no país, na luta pelo domínio do espectro cromático e pelos emblemas nacionais ou internacionais, representando disputas e cisões apenas aparentemente adormecidas desde o início do século XXI. Nas páginas do jornal Folha de S. Paulo do dia 1 de setembro de 2016, anúncio de página inteira na página A9, pago pela Federação das Indústrias do Estado de São Paulo (FIESP), estampava recorte da bandeira do Brasil e chamava união para a reconstrução nacional, ao lado de reportagem sobre a posse do novo presidente (na página A8) cuja manchete era citação de frase do mesmo: "A incerteza acabou. É hora de unir o país".

A mesma edição, em página mais adiante (A12), exibia foto da ex-presidente em seu último dia de mandato. Ali predominava o vermelho na roupa de Dilma e de seus apioadores, e a manchete exibia promessa da ex-presidente em fazer oposição "enérgica e incansável" contra "gestão golpista".

Neste processo, o slogan dos anos 1970, "Brasil, ame-o ou deixe-o", ressurgiu nas ruas repaginado ${ }^{6}$ e apareceu inclusive em matéria do jornal Folha de $S$. Paulo do dia 6 de setembro de 2016. Duas fotos: uma com o Congresso Nacional ao fundo e uma instalação na qual se lia em verde a amarelo a inscrição "Eu amo o Brasil", apresentava o olho da legenda "ame-o"; a segunda mostrava uma pichação "Fora Temer" em arquibancada montada para o desfile de 7 de setembro na Esplanada, cujo olho da legenda era "deixe-o".

Apontava-se a cisão nacional entre presumidos amigos e inimigos da pátria, os primeiros associados ao verde e amarelo, embora a definição de pátria e as maneiras de se garantir uma representatividade real sejam complexas e escapem a limitações binárias como se procurou fazer crer neste episódio recente da história do Brasil e em tantos outros.

Rememorem-se, por exemplo, os gritos de "vai para Cuba" e "vai para Miami", proferidos por faç̧⿸丆es dos dois grupos opositores, expressando a dificuldade de diálogo e a vontade de se ver livre do outro em territorio considerado propriedade exclusiva dos que pensam da mesma maneira e se consideram os verdadeiros "amigos" do país, embora a afirmação do amor à pátria seja mais frequente no grupo que saiu às ruas de verde e amarelo. 


\section{Bandeiras em São Paulo}

No final de março de 2018, a Ponte das bandeiras na zona Norte, a Ponte Estaiada na zona sul, as pontes do Morumbi, Bernardo Goldfarb e a Avenida Brasil, na Zona Oeste, receberam bandeiras do Brasil, instaladas em hastes metálicas em ambos sentidos. A entidade denominada Eu Amo o Brasil (EAB) responsável pela aquisição e colocação das mesmas, almejava atingir a marca de 255 flâmulas espalhadas em vias e principais pontes da cidade, para assim "resgatar o patriotismo". A maneira silenciosa do gesto aparentemente pouco incomodou (figura 8)

A prefeitura justificou em nota a autorização pois "não houve investimento público", e ausentou-se da responsabilidade em relação aos usos e invasão do espaço comum alegando a transitoriedade da ocupação. Antes de autorizar, o poder municipal não consultou o Conselho Municipal de Preservação do Patrimônio Histórico, Cultural e Ambiental da Cidade de São Paulo (Conpresp), e defendeu-se: "O responsável pelo projeto deve submetê-lo ao Conpresp. Caso o conselho não aprove o pedido, as bandeiras poderão ser retiradas, uma vez que trata-se de instalação provisória" (Dayrell; Diógenes, 2018).

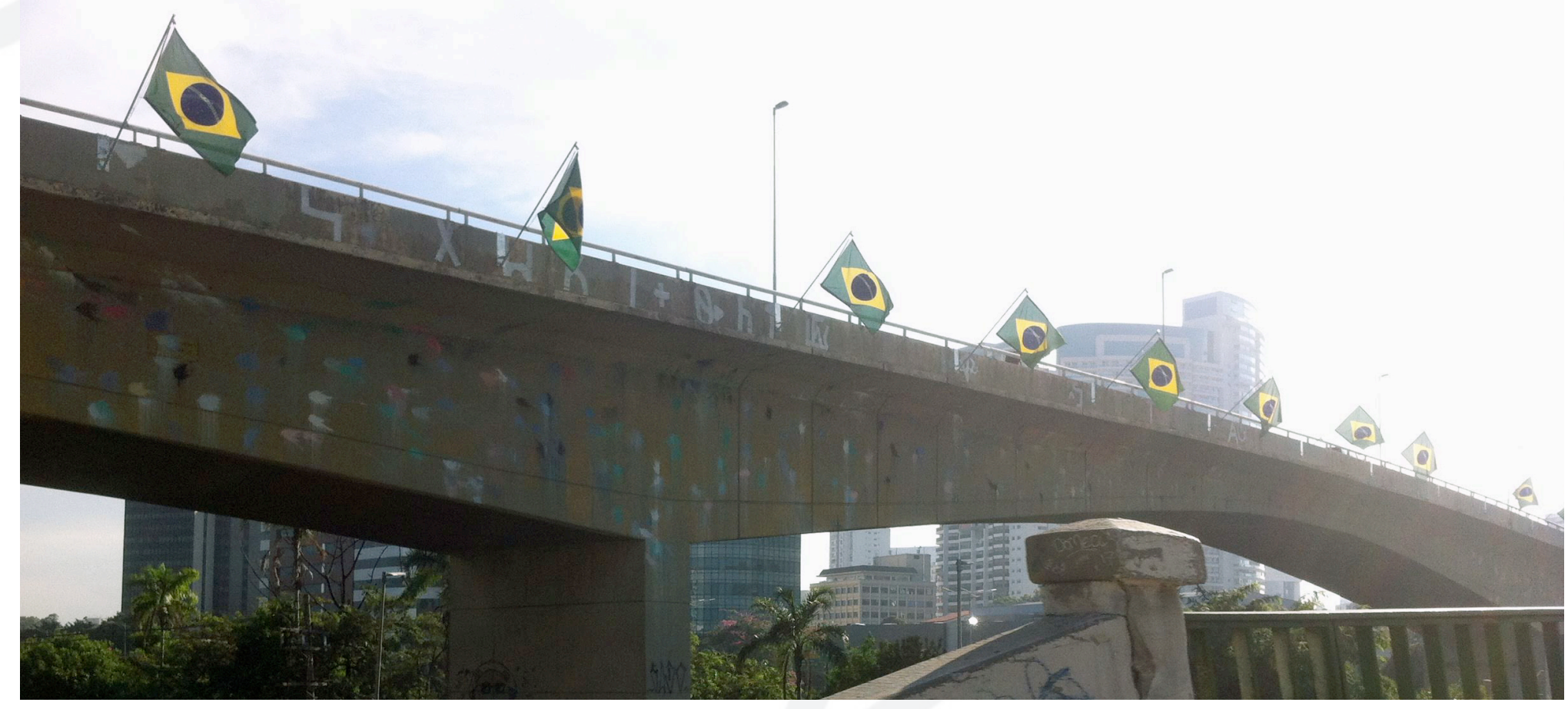

Figura 8: Bandeiras do Brasil instaladas ao longo da ponte Bernardo Goldfarb vista a partir da ponte Eusébio Matoso. Foto: Amanda Saba Ruggiero.

Desde então, as bandeiras permanecem hasteadas nas vias públicas, como uma manifestação tolerável e até desejável pelo poder público local. Mesmo após a deliberação do Conpresp, em 25 de junho de 2018, pela a retirada das bandeiras da Avenida Brasil, cuja área é tombada (Bergamo [2], 2018), os estandartes permanecem na via, sobre pedestais nos quais podem ser lidos os nomes da entidade promotora, do escritório de advocacia do qual faz parte o presidente do movimento EAB e, curiosamente, o logotipo da Prefeitura Municipal de São Paulo (figuras 9 e 10) ${ }^{7}$.

Segundo Mônica Bergamo, colunista do jornal Folha de S. Paulo, após a decisão do Conpresp pela retirada das bandeiras na Avenida Brasil, o advogado José Marcelo Braga Nascimento decidiu entrar com recurso contra a decisão e se manifestou contra a existência do orgão que, segundo ele, "Já devia ter acabado. Já deve ter feito muita bobagem aqui em São Paulo. É um pecado você colocar bandeiras e [ter que] tirar. Um desalento. E por isso que se solta o [ex-ministro] José Dirceu. Eles e que valem" (Bergamo [1], 2018). Diante de tais declarações, fica claro o posicionamento politico de Nascimento. 

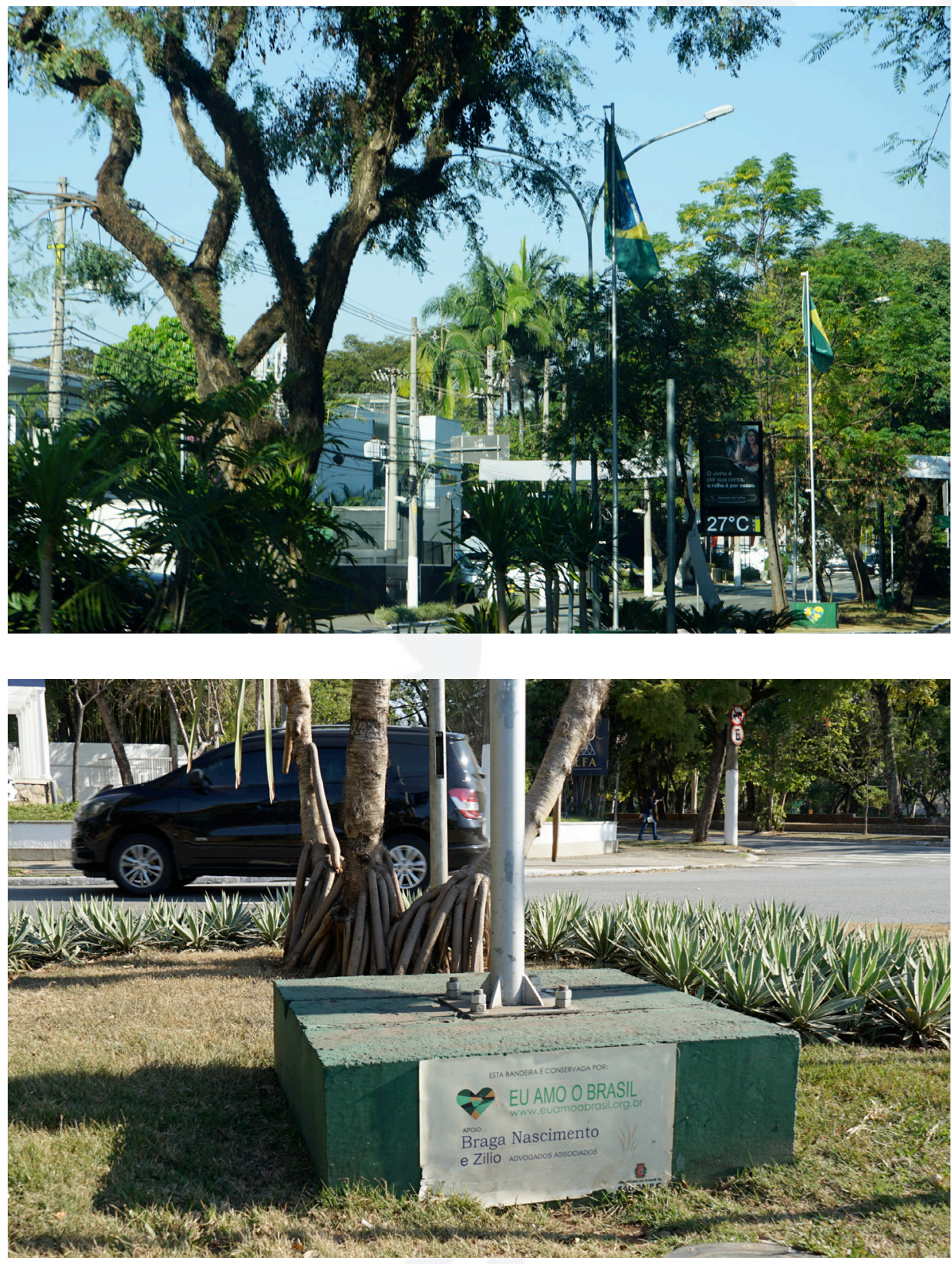

Figuras 9 e 10: Bandeiras do Brasil na Avenida Brasil em foto tirada no dia 28 de junho e pedestal com indicação dos promotores da instalação. Fotos: Luiza Gregori Tokita gentilmente cedidas às autoras.

Pergunta-se: por que o grafite incomoda tanto a gestão municipal atual e as bandeiras, não? Parece ser senso comum que gostar da bandeira nacional e de suas cores predominantes é ser amante da pátria. Em oposição, vestir outras cores e intervenções de outra natureza enquadram-se na categoria do vandalismo, da agressão ao patrimônio, e do desamor ao país, entre outras negatividades.

A EAB, entidade sem fins lucrativos, é presidida pelo advogado José Marcelo Braga Nascimento e criou a campanha Embandeirando São Paulo, por meio da qual instalou as bandeiras para "inspirar o patriotismo", com autorização da Secretaria das Prefeituras Regionais. O caridoso gesto justifica-se alegando que as bandeiras serão doadas ao município, sendo que o aceite das bandeiras do Brasil por parte do poder público aponta para conteúdos difusos e menos explícitos. O escritório de João Marcelo é filiado ao Grupo Lide, empresa do então prefeito João Dória Jr. (MAIS, 2018). A ambição da EAB é atuar efetivamente para mudar o Brasil

\section{Todo aquele que participa da associação, além de quer apenas criticar o que está errado ou se contentar com a indignação, mas vê a necessidade de atuar de forma efetiva para mudar o Brasil. (EAB [Site])}

Ao sair pelas ruas do Butantã, perguntou-se a passageiros de ônibus que desembarcavam na Avenida Vital Brasil e transeuntes das ruas próximas e das pontes Eusébio Matoso e Bernardo Goldfarb se haviam notado as bandeiras do Brasil. Os entrevistados responderam haver reparado na intervenção. Sobre o porquê da colocação das bandeiras do Brasil, a maioria deu como justificativa a Copa do Mundo, momento atual em que o futebol está completamente atado ao símbolo verde amarelo nacional.

Por fim, perguntou-se se sabiam quem havia colocado as bandeiras ali? As pessoas em geral não tinham essa informação, mas faziam suposições. Muitos acreditavam ser uma intervenção da prefeitura, visto tratar-se de espaço público administrado pela municipalidade, mas não tinham certeza. A manifestação foi avaliada positivamente, ou porque julgam interessante ver as bandeiras em tempos de Copa do Mundo, ou porque consideram importante resgatar a união dos brasileiros diante da crise por que passa o país. 
Alguns se manifestaram sobre os grafites pintados sobre a Ponte Bernardo Goldfarb (próxima à Ponte Eusébio Matoso) e disseram gostar das pinturas porque deixam a cidade mais alegre e mais colorida, assim como as bandeiras nacionais, afirmaram.

\section{CONCLUSÃO}

Será que a mera instalação de bandeiras do Brasil pode resultar em alguma mudança de comportamento na população, a ponto de transformar de forma efetiva a realidade do nosso país? O que foi possível notar nas respostas às entrevistas, é que há um desejo de pacificação social no Brasil, ainda que isso seja superficial, não necessariamente resultando em mudança de comportamento, pintado em tintas nas cores verde e amarela e expresso em tempos de Copa do Mundo de futebol, um potente fator de agregação nacional.

Por outro lado, a vontade de unir e pacificar o país tem sido frequentemente acompanhada de manifestações ultranacionalistas de viés autoritário, nada pacificadoras. Pelo contrário, são incentivadoras do ódio a tudo o que seja diferente dentro ou fora do país e capazes de utilizar recursos dos mais violentos em nome dos chamados bons costumes (definidos segundo um padrão único e bastante inflexível), buscando uma homogeneização que não reflete nem representa grande parte da população nacional com sua diversidade de tipos e práticas.

Cabe, assim, a pergunta: Somente o patriotismo pode nos salvar? Para que investir em ações exaltando nacionalismo, sabendo que historicamente ta ação já foi precursora de extermínios em massa ao redor do mundo? Enfim, para as pessoas que circulam pela cidade, qual é a mensagem? Por meio das entrevistas conclui-se que o patriotismo se reforça muito mais pelo futebol do que pela mera instalação de bandeiras. Por outro lado, parece ser senso comum que a instalação de bandeiras nacionais em espaços públicos decorre de ações do poder público, o que, neste caso, não procede diretamente, embora conte-se com a tolerância da municipalidade
Camadas sobrepostas desse imaginário verde e amarelo hoje embaralham-se com o imaginário da copa, misturado com o patriotismo e com o discurso do fazer o bem para o país, em contraposição ao mal, representado pelo que é diferente. Um dos problemas de tal narrativa é acentuar o discurso do ódio dos dois lados, sem meio-termo, sem equilíbrio e sem nuances, em dicotomia maniqueísta e perigosa.

Outra questão polêmica é quem pode atuar sobre o espaço público, neste caso o poder público atua de forma autoritária, mas aparentemente enverniza-se de boas intenções ao utilizar as cores da bandeira, sem exercer consulta das entidades representantes da população para debate sobre as possíveis formas de intervenção nos espaços urbanos. Como aponta o filósofo francês, Jacques Rancière:

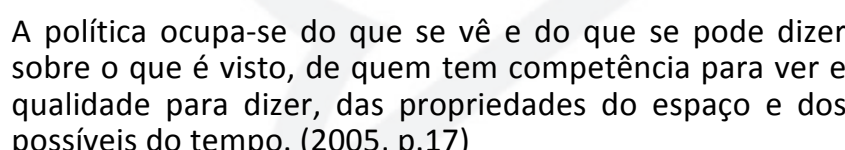
possiveis do tempo. (2005, p.17)

Trata-se de uma disputa pela hegemonia do país expressa no âmbito simbólico/imaginário e sobre o território da cidade. A contenda surge aplainada e pretensamente pacificada pela utilização das cores da bandeira, cujo emprego aproveita a dramaticidade da aura simbólica sagrada do estandarte nacional, multiplicado e repetido ao longo de vias e pontes, inclusive hasteado em mastros, reiterando a dignidade do objeto como símbolo nacional. Mas a inviolabilidade do símbolo serve para calar o contraditório e as manifestações dissonantes, em caminho de mão única cujos desdobramentos podem ser terríveis, sobretudo aos que não ocupam lugares de poder político ou econômico e apenas podem torcer pela conquista da Copa do Mundo de futebol.

\section{REFERÊNCIAS}

Albin, R. C. Dicionário Cravo Albin da Música Popular Brasileira. Disponível em: <http://dicionariompb.com.br>. Acesso em 14 jun. 2018.

Bergamo, M [1]. Doador de bandeiras da avenida Brasil defende o fim de órgão de patrimônio. Folha de S. Paulo, 01 jul. 2018 
[2]. Órgão de patrimônio pede remoção de bandeiras nacionais na avenida Brasil. Folha de S. Paulo, 26 jun. 2018.

Chauí, M. O Verdeamarelismo. In: Brasil, mito fundador e sociedade autoritária. São Paulo: Fundação Perseu Abramo; 2001.

Dayrell, M; Diógenes, Juliana. Doria autoriza instalação de bandeiras do Brasil em pontes sem consultar Conpresp. O Estado de S.Paulo. 30 Março 2018.

Freyre, G. Ordem e progresso. Rio de Janeiro: José Olympio; 1959 [1957].

Hall, S. A identidade cultural na pós-modernidade. Tradução: Tomaz Tadeu da Silva e Guacira Lopes Louro. Rio de Janeiro: Lamparina; 2015.

Luz, M. A história dos símbolos nacionais : a bandeira, o brasão, o selo, o hino / Milton Luz. - Brasília: Senado Federal/Secretaria Especial de Editoração e Publicações; 2005 [1999].

Mais, duas pontes de São Paulo recebem bandeiras do Brasil. G1, 28 mar.

2018. Disponível em: <https://g1.globo.com/sp/sao-paulo/noticia/maisduas-pontes-de-sao-paulo-recebem-bandeiras-do-brasil.ghtml>. Acesso em 26 jun. 2018.

Mota, C. G.; LOPEZ, A. História do Brasil: uma interpretação. São Paulo: Editora 34; 2015.

Ortiz, R. Cultura brasileira e identidade nacional. São Paulo: Brasiliense; 1985.

Picchia, M. et al. Nhengaçu Verde-Amarelo. Correio Paulistano, 17 mai. 1929. In: SCHWARTZ, Jorge. Vanguardas latino-americanas: polêmicas, manifestos e textos críticos. São Paulo: EDUSP, 2008.

Rodrigues, V. 2013 e a violência do Estado (esquecida no churrasco). Correio da Cidadania, 14 jun. 2018. Disponível em: <http://www.correiocidadania.com.br/2-uncategorised/13320-2013-e-aviolencia-do-estado-esquecida-no-churrasco>. Acesso em 15 jun. 2018.

Rancière, J. A Partilha do sensível: Estética e política. Trad. Mônica Costa Neto. São Paulo: Ed. 34; 2005.

Schwartz, J. Vanguardas latino-americanas: polêmicas, manifestos e textos críticos. São Paulo: EDUSP; 2008.

\section{ARTIGOS/ENSAIOS}

